\title{
Genetic Diversity of Potato virus Y in Potato Production Areas in Northeast China
}

Yanju Bai, Northeast Agricultural University, Harbin, Heilongjiang 150030, China; Heilongjiang Academy of Agricultural Sciences, Harbin, Heilongjiang 150086, China; Shuxin Han, Northeast Agricultural University, Harbin, Heilongjiang 150030, China; Yanling Gao, Northeast Agricultural University, Harbin, Heilongjiang 150030, China; Heilongjiang Academy of Agricultural Sciences, Harbin, Heilongjiang 150086, China; Wei Zhang, Guoquan Fan, and Cailing Qiu, Heilongjiang Academy of Agricultural Sciences, Harbin, Heilongjiang 150086, China; Xianzhou Nie, ${ }^{\dagger}$ Fredericton Research and Development Centre, Agriculture and Agri-Food Canada, Fredericton, New Brunswick, Canada E3B 4Z7; and Jingzhi Wen, ${ }^{\dagger}$ Northeast Agricultural University, Harbin, Heilongjiang 150030, China

\begin{abstract}
In 2011-2014, ELISA or nucleic acid spot hybridization (NASH) testing for common potato viruses or Potato spindle tuber viroid (PSTVd) was performed on 500 leaf samples collected in potato fields in the northeast provinces Heilongjiang and Inner Mongolia, China. The results revealed that $38.4 \%$ (Heilongjiang) and $27.7 \%$ (Inner Mongolia) were positive for Potato virus $Y$ (PVY). To unveil the strain composition and population structure of PVY in the region, the multiplex RT-PCR described by Chikh-Ali et al. was performed on all of the ELISA-PVY-positive samples. Of the 158 samples whose PVY strain scenarios could be determined, PVY ${ }^{\mathrm{NTN}-\mathrm{NW}}-\mathrm{SYR}-\mathrm{II}$ and PVY ${ }^{\mathrm{N}-\mathrm{Wi}}$ were the most abundant strains, occurring in 58.9 and $47.5 \%$ samples, followed by PVYNTN${ }^{N^{2}}$-SYR-I (31.0\%), PVY ${ }^{\mathrm{N}: \mathrm{O}}(19.6 \%)$, Eu-PVY ${ }^{\mathrm{NTN}}(7.6 \%), \mathrm{NA}^{\mathrm{P}} \mathrm{PVY}{ }^{\mathrm{N}}$ $(1.3 \%)$, and $\mathrm{PVY}^{\mathrm{O}}(0.6 \%)$. In the 84 single-strain-infected samples, PVY $Y^{\mathrm{N}-\mathrm{Wi}}$ accounted for $41.7 \%$, PVY ${ }^{\mathrm{NTN}-\mathrm{NW}}-\mathrm{SYR}-\mathrm{II}$ for $40.5 \%$, PVY $^{\mathrm{NTN}-N W}-\mathrm{SYR}-\mathrm{I}$ for $14.3 \%$, and PVY ${ }^{\mathrm{N}: \mathrm{O}}$ and Eu-PVY ${ }^{\mathrm{NTN}}$ for $3.6 \%$ each. Seven isolates representing PVY ${ }^{\mathrm{NTN}-N{ }_{-}}$-SYR-I (HLJ-6-1 and HLJ-9-4), PVY ${ }^{\text {NTN-NW }}-$ SYR-II (INM-W-369-12 and SC-1-1-2),

$\mathrm{PVY}^{\mathrm{N}: \mathrm{O}}$ (HLJ-30-2), and PVY ${ }^{\mathrm{N}-\mathrm{Wi}}$ (HLJ-BDH-2 and HLJ-C-429) were sequenced and analyzed molecularly. Whereas the sequence identities for isolates belonging to the same strain group were $>98.5 \%$, they fell for isolates belonging to different strain groups to $92.7-98.1 \%$ at the genome level and $96.1-98.4 \%$ at the polyprotein level. Interestingly, the exact location of the recombination events varied among isolates within a strain group. Phylogenetic analysis of all 42 full length PVY sequences from China indicated that most clustered to various recombinant groups, despite the fact that the PVY isolates were isolated from at least five host species. Pathological analysis of four isolates representing $\mathrm{PVY}^{\mathrm{N}: \mathrm{O}}, \mathrm{PVY}^{\mathrm{N}-\mathrm{Wi}}, \mathrm{PVY}^{\mathrm{NTN}-\mathrm{NW}}-\mathrm{SYR}-\mathrm{I}$, and PVYNTN-NW $-S Y R-I I$ revealed that the PVY ${ }^{\text {NTN-NW }}$-SYR-II isolate incited the most severe symptoms on potato cultivar Kexin 13, followed

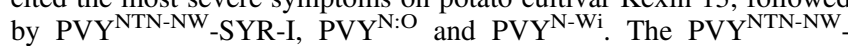
SYR-I and PVY ${ }^{\text {NTN-NW }}$-SYR-II isolates also caused necrotic ringspots on the tubers of Kexin 13, indicating their ability to induce the potato tuber necrotic ringspot disease in potato.
\end{abstract}

Potato (Solanum tuberosum L.) is one of the most important food crops in China, serving as both a staple food for people in many remote and mountainous areas and a vegetable for the whole population (Gao et al. 2013). Due to its significance in the Chinese economy and food supply, potato was officially designated as the "staple" food crop by the Chinese government in 2016 (Zhang et al. 2017). Potato is grown widely in China, ranging from the subtropical provinces $\left(\sim 22-24^{\circ} \mathrm{N}\right)$, such as Guangdong and Guangxi, to the far northeast region $\left(\sim 46-49.5^{\circ} \mathrm{N}\right)$ including Heilongjiang and Inner Mongolia. In the subtropical area, potato is planted as a winter crop in the rice paddy fields after rice is harvested (Wang et al. 2017), whereas in the northeast region, where only one cropping season is possible, potato is cultivated in the summer. Due to the diverse cropping systems and complicated environmental conditions, potato production in China faces numerous challenges. One of the challenges is the production and utilization of quality seeds (Qu and Xie 2009).

Potato virus $Y$ (PVY, genus Potyvirus, family Potyviridae) infection is one of the constraints that affect both seed and commercial potato productions in China (Wang et al. 2014). The virus has multiple strains and substrains, including the conventional (nonrecombinant) strains $\mathrm{PVY}^{\mathrm{O}}, \mathrm{PVY}^{\mathrm{N}}$, and $\mathrm{PVY}^{\mathrm{C}}$ (Jones 1990) as well as various

${ }^{\dagger}$ Corresponding authors: J. Z. Wen, E-mail: jzhwen2000@163.com; X. Nie, E-mail: xianzhou.nie@agr.gc.ca

Funding: China Agriculture Research System (CARS-09-P16).

*The $\boldsymbol{e}$-Xtra logo stands for "electronic extra" and indicates that three supplementary tables and three supplementary figures are published online.

Accepted for publication 4 August 2018.

C 2019 The American Phytopathological Society

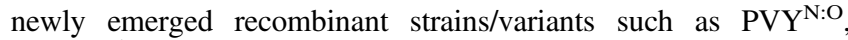
PVY ${ }^{\mathrm{N}-\mathrm{Wi}}$, Eu-PVYNTN, and PVY ${ }^{\mathrm{NTN}-\mathrm{NW}}$ (Chikh-Ali et al. 2010a, b; Karasev and Gray 2013). The virus incites a wide range of symptoms on potato, depending on PVY strain and potato cultivar (Nie et al. 2012). In general, $P V Y^{O}$ causes more severe symptoms than other strains on plants of most potato cultivars. However, PVYNTN and PVY ${ }^{\mathrm{NTN}-\mathrm{NW}}$ can cause potato tuber necrotic ringspot disease (PTNRD) on sensitive cultivars (Hu et al. 2009a; Nie et al. 2012), thus making the affected tubers unmarketable. These strains, together with PVY ${ }^{\mathrm{N}: \mathrm{O}}$ and $\mathrm{PVY} \mathrm{Y}^{\mathrm{N}-\mathrm{Wi}}$, all recombinant strains, have replaced $\mathrm{PVY}^{\mathrm{O}}$, a nonrecombinant strain, to become the most common strains in many potato growing areas around the world, including Europe (Kamangar et al. 2014), the Middle East (Chikh-Ali et al. 2010a, b, 2016), the United States (Funke et al. 2017; Karasev et al. 2011), and Canada (MacKenzie et al. 2018). PVY can also infect several other important horticultural crops belonging to the Solanaceae family such as tomato, eggplant, tobacco, and chili pepper (Shukla et al. 1994). The veinal necrosis-inducing strains, including $P V Y^{\mathrm{N}}, \mathrm{PVY}^{\mathrm{N}: \mathrm{O}}$, $\mathrm{PVY}^{\mathrm{NTN}}$, and $\mathrm{PVY}^{\mathrm{N}-\mathrm{Wi}}$, can cause severe leaf necrosis and leaf death on infected tobacco plants, leading to a high level of economic loss in tobacco production (Tian et al. 2011; Wan et al. 2015; Wang et al. 2012a). Despite the economic significance of PVY on potato and tobacco production, little research has been performed systematically to unveil the strain composition and molecular properties of $\mathrm{PVY}$ in potato production systems in China.

The far northeast region is the biggest potato producing area in China, accounting for $13.5 \%$ of China's total potato production (Chinese Ministry of Agriculture 2017). Moreover, the region also serves as the major seed potato production area for the country, providing up to $60 \%$ of the nation's certified seed potatoes (Y. Bai, unpublished data). The quality of the seeds produced in this region directly impacts national potato production and the potato industry. Keeping this in mind, this research aimed (1) to survey the occurrence of viruses, viroids included, in potato crops in the far northeast region 
including Heilongjiang and Inner Mongolia; (2) to unveil the PVY strain composition, the molecular properties of representative isolates, and their phylogenetic relationship with PVY isolates reported in China to date; and (3) to investigate the pathogenicity of the representative PVY isolates on a common potato cultivar Kexin 13. The results demonstrate that PVY was the most common virus occurring in potato crops in the region. Recombinant strains, including $\mathrm{PVY}^{\mathrm{N}-\mathrm{Wi}}, \mathrm{PVY}^{\mathrm{N}: \mathrm{O}}$, PVY ${ }^{\text {NTN-NW }}$-SYR-I, PVY ${ }^{\text {NTN-NW }}$-SYR-II, and Eu-PVY ${ }^{\text {NTN }}$, accounted for $>95 \%$ of the PVY population, with PVY ${ }^{\text {NTN-NW }}$-SYR-II and $\mathrm{PVY}^{\mathrm{N}-\mathrm{Wi}}$ being the predominant strains.

\section{Materials and Methods}

Survey for viruses/viroid in potato crops. From 2011-2014, a total of 500 leaf samples were collected from potato production areas from mid-July to mid-August (the middleof the the growing season) in the northeast provinces Heilongjiang $(n=276)$ and Inner Mongolia $(n=224)$ (Fig. 1), based mainly on the abnormal appearance of the foliage such as mosaic, stunting, and necrosis. The samples were immediately placed into a cooler containing an icepack, and shipped to the laboratory at the Heilongjiang Academy of Agricultural Sciences (HAAS), Harbin, Heilongjiang, China, for analysis.

Enzyme-linked immunosorbent assay (ELISA) and nucleic acid spot hybridization (NASH). Double-antibody sandwichELISA with virus-specific antibodies (Adgen, Ayr, U.K.) was used to detect various viruses, including PVY, Potato virus X (PVX), Potato virus A (PVA), Potato virus $M$ (PVM), Potato virus $S$ (PVS), and Potato leafroll virus (PLRV) following the antibody supplier's instructions. The positive and negative controls provided by the manufacturer were included in each ELISA to ensure the success of the assay. A sample was considered positive when the absorbance at
$405\left(\mathrm{~A}_{405}\right)$ was greater than three times the average value of the negative controls. For serotyping PVY-positive samples, the $\mathrm{PVY}^{\mathrm{N}}$ - and

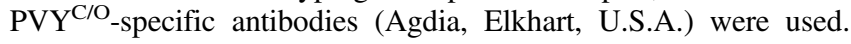
Meanwhile, NASH was used to detect Potato spindle tuber viroid (PSTVd) in the samples (Lu et al. 2009).

PVY isolates and inoculation experiments. Six samples (HLJ-61, HLJ-9-4, HLJ-30-2, HLJ-C-429, HLJ-BDH-2, and INM-W-36912) that were found to be infected exclusively with a single strain of PVY of interest based on ELISA tests and RT-PCR assays (see following) were selected for further molecular and pathological studies. In addition, a PVY isolate (SC-1-1-2), which was collected in the southwest province of Sichuan in 2014 and was determined to be PVY $^{\text {NTN-NW }}$-SYR-II by RT-PCR (Chikh-Ali et al. 2010b), was also included for the investigation. The leaf samples were ground in inoculation buffer (10 mM sodium phosphate buffer, $\mathrm{pH} 7.5$, with $32 \mathrm{mM}$ $\mathrm{Na}_{2} \mathrm{SO}_{3}$ ) at a 1:10 ratio (leaf w:buffer vol) and then mechanically inoculated into tobacco (Nicotiana tabacum cultivar Xanthi nc) seedlings $(\sim 5$ leaf stage) in the greenhouse as described in Han et al. (2017). The infection was confirmed by ELISA and RT-PCR 10 days post inoculation (DPI). Symptoms were recorded soon after the inoculation for up to 3 weeks. The tobacco plants were then used as culture hosts for the inoculation of potato plants.

Kexin 13, a common potato cultivar in northeast China (Sun et al. 2001), was used to study the pathogenicity of the PVY isolates. The cultivar is susceptible to PVY infection (Bai et al. 2017). Virus-free tubers of Kexin 13 were planted in a greenhouse with a photoperiod of $16: 8 \mathrm{~h}$ (day:night). The temperature was set at $24 / 18^{\circ} \mathrm{C}$ (day/night) and the humidity at $75 \%$. When the plants reached the 4-6 leaf stage, they were mechanically inoculated with an appropriate PVY isolate (Han et al. 2017). Briefly, leaves of PVY-infected tobacco plants (see

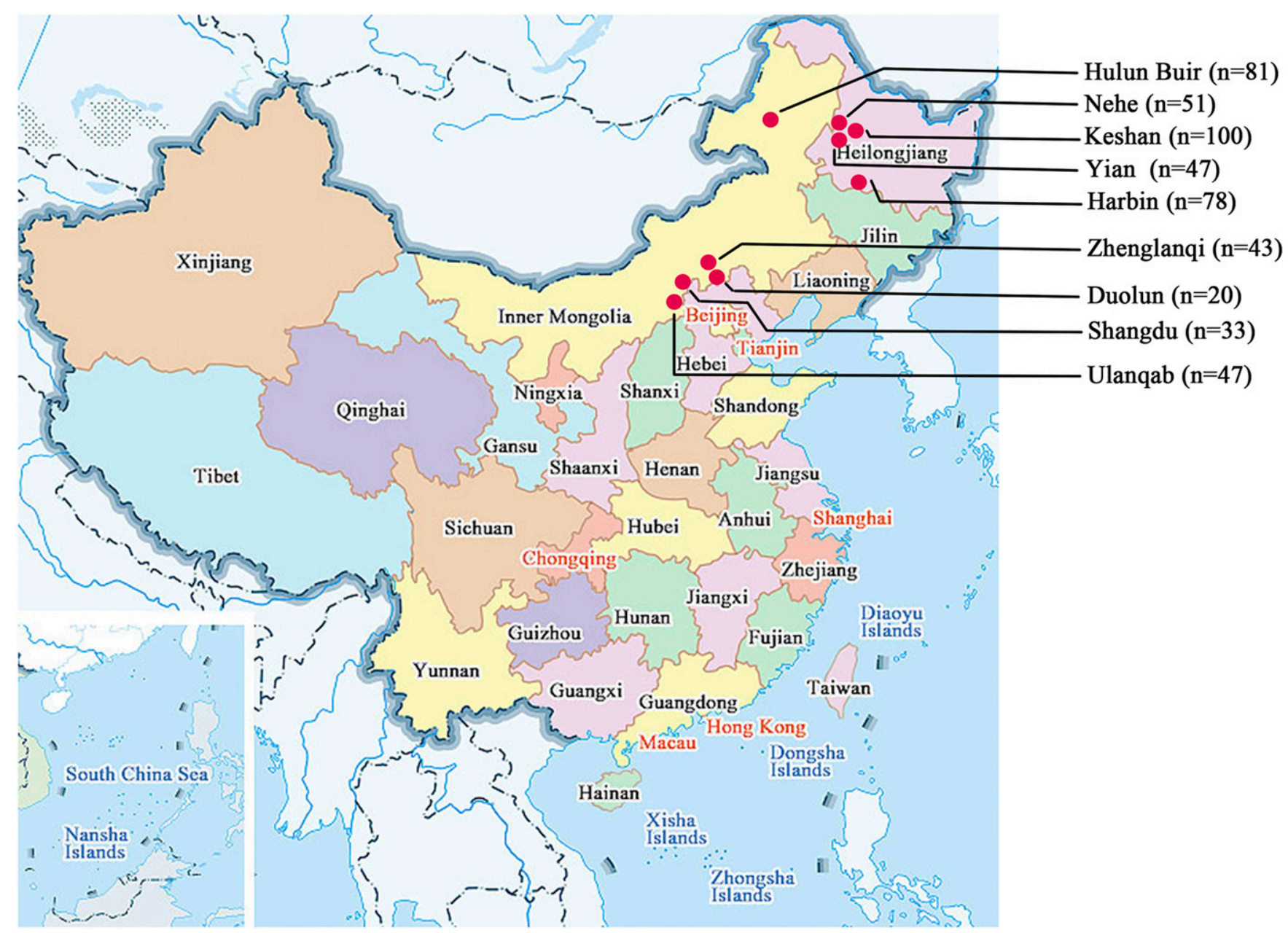

Fig. 1. A map of China indicating the locations where samples were collected. Dots indicate the sampling locations. The city/county name and the number of samples for each location are shown outside the map. 
above) were ground in the inoculation buffer at a 1:10 ratio (leaf w: buffer vol). The top two leaves of the potato plants were dusted with carborundum and rubbed gently with a pestle in the presence of $\sim 0.5 \mathrm{ml}$ of virus extract or inoculation buffer (control) per leaf. The plants were then maintained in the greenhouse under the conditions described above until harvesting. Each treatment contained five plants, and the experiments were repeated three times.

RNA extraction and RT-PCR detection of PVY strains. The total RNA was extracted using the Trizol method (Simms and Ellis 1996). Briefly, $0.1 \mathrm{~g}$ of leaf tissue was ground in $1 \mathrm{ml}$ of Trizol (Invitrogen, Carlsbad, CA, U.S.A.) following the manufacturer's manual. The RNA was then quantified spectrophotometrically, adjusted to a concentration of $1,500 \mathrm{ng} / \mu \mathrm{l}$, and stored at $-80^{\circ} \mathrm{C}$. A total of $3 \mu \mathrm{l}$ of RNA together with $1 \mu \mathrm{l}$ of random hexanucleotide primers $(500 \mathrm{ng} / \mu \mathrm{l})$ and $1 \mu \mathrm{l}$ of RNase-free $\mathrm{H}_{2} \mathrm{O}$ was incubated at $70^{\circ} \mathrm{C}$ for $5 \mathrm{~min}$ and chilled on ice immediately. Thereafter, $15 \mu \mathrm{l}$ of ImProm-II Reverse Transcription mix (Promega, Madison, WI, U.S.A.) was added into the tube containing the denatured RNA for cDNA synthesis following the manufacturer's instructions.

Multiplex PCR for detection of different PVY strains was performed using primers reported in Chikh-Ali et al. (2010b) (Supplementary Table S1). The PCR was performed in a PTC-0200 DNA Engine thermal cycler (BIO-RAD Laboratories, Hercules, CA, U.S.A.). After the reaction, $10 \mu \mathrm{l}$ of PCR product was loaded onto a $1.2 \%$ agarose gel for electrophoresis, and visualized under UV illumination after staining with ethidium bromide $(0.5 \mu \mathrm{g} / \mathrm{ml})$.

PVY genome sequencing. To determine the complete genome sequence, nine overlapping fragments covering the whole genome were amplified by RT-PCR using the primers reported in Nie and Singh (2003a) (Supplementary Table S2). PCR was performed with Prime STAR Max DNA Ploymerase in a PTC-0200 DNA Engine thermal cycler. The PCR cycling conditions were: $92^{\circ} \mathrm{C} 5 \mathrm{~min}$; five cycles of $92^{\circ} \mathrm{C} 30 \mathrm{~s}, 62^{\circ} \mathrm{C} 45 \mathrm{~s}, 72^{\circ} \mathrm{C} 90 \mathrm{~s}$; five cycles of $92^{\circ} \mathrm{C} 30 \mathrm{~s}$, $60^{\circ} \mathrm{C} 45 \mathrm{~s}, 72^{\circ} \mathrm{C} 90 \mathrm{~s} ; 10$ cycles of $92^{\circ} \mathrm{C} 30 \mathrm{~s}, 58^{\circ} \mathrm{C} 45 \mathrm{~s}, 72^{\circ} \mathrm{C} 90 \mathrm{~s}$; and 10 cycles of $92^{\circ} \mathrm{C} 30 \mathrm{~s}, 55^{\circ} \mathrm{C} 45 \mathrm{~s}, 72^{\circ} \mathrm{C} 90 \mathrm{~s}$, followed by a final step of $10 \mathrm{~min}$ at $72^{\circ} \mathrm{C}$. After the targeted amplicons were recovered as described in Han et al. (2017), they were ligated into pEASY-T5 TA cloning vector (TransGen Biotech, Beijing, China). The ligated plasmids were transferred into Trans1-T1 phage resistant competent cells (TransGen Biotech) following the manufacturer's instructions. Five clones for each amplicon were selected randomly and sequenced by the Sanger method at the Beijing Genomics Institute (Beijing, China). The complete genome sequence was then compiled as described in Han et al. (2017).

Sequence analysis and phylogeny. Sequence identities between virus isolates were analyzed using BLAST (https://www.ncbi.nlm. nih.gov/BLAST). For recombination event (RE) and phylogeny analyses, the complete genome sequences of PVY, including the sequences reported in this study as well as the sequences of representative isolates/strains, such as $\mathrm{N605}$ (X97895) $\left(\mathrm{PVY}^{\mathrm{N}}\right), \mathrm{Oz}$ (EF026074) (PVYO), HN2 (GQ200836) (PVYNTN-NW_SYR-I), SYR-II-2-8 (AB461451) (PVY ${ }^{\text {NTN-NW }}-$ SYR-II), SGS-AG (JQ924288) (PVY ${ }^{\mathrm{N}-\mathrm{Wi}}$ ), Mb112 (AY745491) (PVYN:O), Hungarian (M95491) (Eu-PVY ${ }^{\text {NTN }}$ ), and SYR-III-L4 (AB461454) (PVYNTN-NW $\left.-S Y R-I I I\right)$ were aligned using Clustal Omega (https://www.ebi.ac.uk/Tools/msa/ clustalo/). The aligned sequences were then subjected to phylogenetic analysis using MEGA7 software (Kumar et al. 2016) or RE analysis using SimPlot (Lole et al. 1999). Different recombination detection programs, including RDP, BootScan, Chimaera, MaxChi, and 3 Seq programs in RDP4 software (version 4.71) (Martin et al. 2015) were used for more accurate detection of breakpoints of recombination. A sequence was considered "recombinant" if the recombination event was detected by at least four of the methods in RDP with $P$ values $<1 \times$ $10^{-10}$ ).

\section{Results}

Occurrence of viruses, including PSTVd, in potato crops in Heilongjiang and Inner Mongolia. Of the 276 samples collected in Heilongjiang over 2011-2014, PVY was detected in 106 samples, accounting for $38.4 \%$ of the total samples. Other viruses, including
PSTVd, occurred at a much lower rate: $0 \%$ for PVA, PVM, and PVX; $1.1 \%$ for PSTVd; $2.9 \%$ for PLRV; and $4.0 \%$ for PVS. A similar trend was also observed in Inner Mongolia: PVY was detected in $27.7 \%$ of the 224 samples collected, whereas other viruses, PSTVd included, were found at a much lower rate: $6.3 \%$ for PLRV, $0 \%$ for PVA, $1.3 \%$ for PVM, $4.0 \%$ for PVS, $0.9 \%$ for PVX, and $0.4 \%$ for PSTVd (Table 1).

PVY strain structure in potato crops. As shown in Supplementary Figure S1, several different band patterns corresponding to different PVY strains were obtained from the PVY-positive samples. These strains include PVY ${ }^{\mathrm{O}}, \mathrm{NA}-\mathrm{PVY}^{\mathrm{N}}, \mathrm{PVY}^{\mathrm{N}-\mathrm{Wi}}, \mathrm{PVY}^{\mathrm{NTN}-\mathrm{NW}}$ SYR-I, PVY ${ }^{\text {NTN-NW }}$-SYR-II, and PVY ${ }^{\text {NTN-NW }}$-SYR-III, thus demonstrating the existence of multiple strains of PVY in potato crops in the region. RT-PCR analysis of the 168 ELISA-PVY-positive samples revealed a complex infection scenario: 84 samples were infected with only one PVY strain, while 74 samples were infected with more than one strain of PVY (Fig. 2). There were 10 samples whose strain status could not be determined. PVY ${ }^{\text {NTN-NW }}$-SYR-II and $\mathrm{PVY} \mathrm{Y}^{\mathrm{N}-\mathrm{Wi}}$ were the most widely distributed strains, being found in 93 (58.9\%) and 75 (47.5\%) samples, respectively, followed by PVY ${ }^{\text {NTN-NW }}$-SYR-I $\quad(31.0 \%), \quad$ PVY ${ }^{\mathrm{N}: \mathrm{O}} \quad(19.6 \%), \quad$ Eu-PVY ${ }^{\mathrm{NTN}}$ (7.6\%), NA-PVY ${ }^{\mathrm{N}}(1.3 \%)$, and $\mathrm{PVY}^{\mathrm{O}}(0.6 \%)$. In the 84 singlestrain-infected samples, PVY ${ }^{\mathrm{N}-W \mathrm{P}}$ accounted for $41.7 \%$, followed by PVY ${ }^{\text {NTN-NW }}$-SYR-II (40.5\%), PVYNTN-NW-SYR-I (14.3\%), and $\mathrm{PVY}^{\mathrm{N}: \mathrm{O}}$ and Eu-PVY ${ }^{\mathrm{NTN}}$ (3.6\% each). The results clearly demonstrate the existence of diverse strains of PVY in potato crops in the main potato production areas in China. Moreover, as in many other potato production areas in the world, the recombinant strains are the predominant strain groups in the potato crops.

Molecular analysis of representative PVY isolates. Although the RT-PCR assay can categorize PVY into various groups based on characteristic sequence features such as recombination junctions (RJs) (Chikh-Ali et al. 2010b; Nie and Singh 2003b), the ultimate characterization of molecular diversity should come from the complete genome sequence analysis. Seven isolates that represented the most common strains found in the single infection scenarios were selected for molecular and pathological characterization. These isolates included: HLJ-6-1 and HLJ-9-4 (PVYNTN-NW $-S Y R-I)$, SC-1-

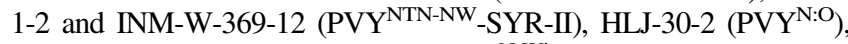
and HLJ-BDH-2 and HLJ-C-429 (PVYN-Wi). The complete genome sequences of the isolates were determined and deposited to GenBank with accession numbers: HLJ-BDH-2, KX032614; HLJ-61, KX688597; HLJ-9-4, KX688598; HLJ-30-2, KX688599; HLJC-429, KX688600; INM-W-369-12, KX688601; SC-1-1-2, KX688602.

The genome size of the isolates ranged from 9,697 to 9,702 bp, excluding poly (A) tail. All isolates encoded a polyprotein of 3,061 amino acids in their respective conventional open reading frames (ORF) of 9,186 bp. The unconventional ORF, pretty interesting Potyviridae ORF (pipo), was also found in all isolates (data not shown). The genome size and sequence identity analyses at the complete genome level and polyprotein level are summarized in Supplementary Table S3. Highest sequence identities were found between isolates belonging to the same strain group. For instance, HLJ-9-4 and HLJ-6-1, both being categorized as PVY ${ }^{\mathrm{NTN}-\mathrm{NW}_{-}}$-SYR-I by the RTPCR assay, shared 99.5 and $99.4 \%$ sequence identities at the complete genome and the polyprotein levels, respectively; HLJ-C-429 and HLJ-BDH-2, both being categorized as PVY ${ }^{\mathrm{N}-\mathrm{Wi}}$, shared 98.6 and $98.9 \%$ identities at the genome and polyprotein levels; SC-1-12 and INM-W-369-12, being categorized as PVY ${ }^{\text {NTN-NW }}$-SYR-II, shared 99.2 and $99.4 \%$ identities at the genome and polyprotein levels. The intrastrain identities of PVY ranged from $92.7-98.1 \%$ at the genome level and 96.1-98.4\% at the polyprotein level, depending on what strains were compared. At the complete genome level, PVY $^{\text {NTN-NW }}$-SYR-I isolates shared $92.7-93.3 \%, 97.8-98.1 \%$, and 94.0\% identities with $\mathrm{PVY}^{\mathrm{N}-\mathrm{Wi}}, \mathrm{PVY}^{\mathrm{NTN}-\mathrm{NW}}-\mathrm{SYR}-\mathrm{II}$, and PVY ${ }^{\mathrm{N}: \mathrm{O}}$ isolates, respectively; $\mathrm{PVY}^{\mathrm{N}-\mathrm{Wi}^{\mathrm{i}}}$ isolates shared $94.1-94.5 \%$ and 96.8-97.0\% identities with PVY ${ }^{\text {NTN-NW }}-$ SYR-II and PVY ${ }^{\mathrm{N}: O}$ isolates, respectively; PVY ${ }^{\mathrm{NTN}-\mathrm{NW}}-\mathrm{SYR}-\mathrm{II}$ and $\mathrm{PVY} \mathrm{Y}^{\mathrm{N}: \mathrm{O}}$ isolates shared $92.8 \%$ identity. When compared with the representative isolates of 
major strains including $\mathrm{PVY}^{\mathrm{C}}, \mathrm{PVY}^{\mathrm{O}}, \mathrm{NA}-\mathrm{PVY} \mathrm{N}^{\mathrm{N} / \mathrm{NTN}}, \mathrm{Eu}-\mathrm{PVY} \mathrm{Y}^{\mathrm{N}}$,

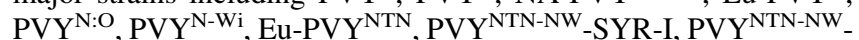
SYR-II, and PVYNTN-NW $-S Y R-I I I$, all the newly obtained isolates exhibited higher sequence identities with the recombinant strains (i.e., $\quad \mathrm{PVY}^{\mathrm{N}: \mathrm{O}}, \quad \mathrm{PVY}^{\mathrm{N}-\mathrm{Wi}}, \quad \mathrm{Eu}-\mathrm{PVY} \mathrm{NTN}^{\mathrm{NTN}}, \mathrm{PVY}^{\mathrm{NTN}-\mathrm{NW}}-\mathrm{SYR}-\mathrm{I}$, PVY ${ }^{\mathrm{NTN}-N W_{-S Y R}}$-II, and PVY $Y^{\mathrm{NTN}-N W_{-S Y R}}$-III) than with the nonrecombinant strains (i.e., $\mathrm{PVY}^{\mathrm{C}}, \mathrm{PVY}^{\mathrm{O}}$, NA-PVY ${ }^{\mathrm{N} / \mathrm{NTN}}$, and $\mathrm{Eu}-$
$\mathrm{PVY}^{\mathrm{N}}$ ) at the complete genome level. For instance, the identities between PVY ${ }^{\mathrm{NTN}-\mathrm{NW}}-\mathrm{SYR}-\mathrm{I}$ isolate HN2 and the newly obtained isolates ranged from $92.9 \%$ (with HLJ-C-429) to $99.6 \%$ (with HLJ-6-1). On the other hand, the identities between Eu-PVY ${ }^{\mathrm{N}}$ isolate N605 and the newly obtained isolates were equal to or less than 92.9\%, ranging from $86.9 \%$ (HLJ-BDH-2) to $92.9 \%$ (HLJ-9-4). It is noteworthy that interstrain variations occurred at different levels:

Table 1. Occurrence of common potato viruses and Potato spindle tuber viroid in leaf samples collected in potato fields in Heilongjiang and Inner Mongolia, China $^{\mathrm{a}}$

\begin{tabular}{|c|c|c|c|}
\hline \multirow[b]{2}{*}{ Virus/viroid } & \multicolumn{2}{|c|}{ Province } & \multirow[b]{2}{*}{ Total $(n=500)$} \\
\hline & Heilongjiang $(n=276)$ & Inner Mongolia ( $(\mathrm{n}=224)$ & \\
\hline Potato leaf roll virus & $8(2.9 \%)$ & $14(6.3 \%)$ & $22(4.4 \%)$ \\
\hline Potato virus $A$ & $0(0 \%)$ & $0(0 \%)$ & $0(0 \%)$ \\
\hline Potato virus $M$ & $0(0 \%)$ & $3(1.3 \%)$ & $3(0.6 \%)$ \\
\hline Potato virus $S$ & $11(4.0 \%)$ & $9(4.0 \%)$ & $20(4.0 \%)$ \\
\hline Potato virus $X$ & $0(0 \%)$ & $2(0.9 \%)$ & $2(0.4 \%)$ \\
\hline Potato virus $Y$ & $106(38.4 \%)$ & $62(27.7 \%)$ & $168(33.6 \%)$ \\
\hline Potato spindle tuber viroid & $3(1.1 \%)$ & $1(0.4 \%)$ & $4(0.8 \%)$ \\
\hline
\end{tabular}

${ }^{\text {a }}$ The viruses were detected by ELISA with virus-specific antibodies as described in the text, and Potato spindle tuber viroid was detected by nucleic acid spot hybridization (NASH). A sample was considered positive in ELISA assay when the absorbance at $405 \mathrm{~nm}$ was greater than three times the average value of the negative controls. $\mathrm{n}=$ number of samples.

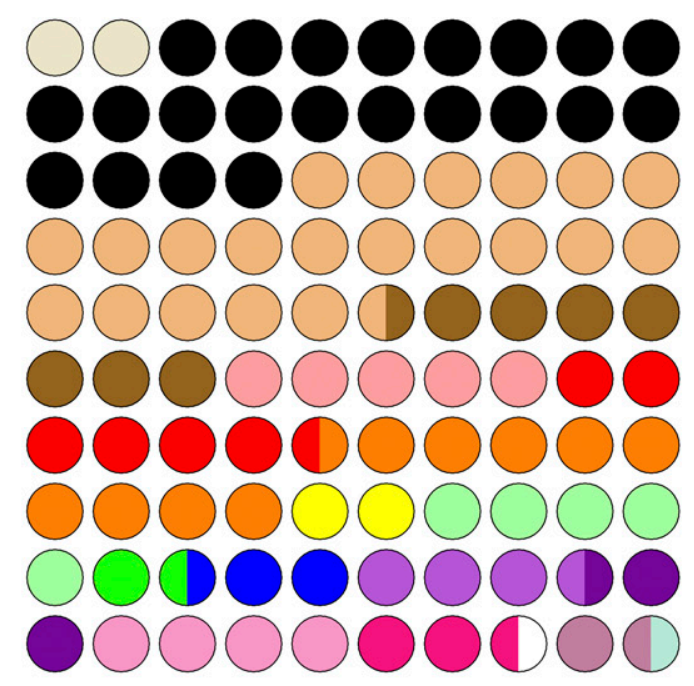

\section{Total $=158$}

$1.9 \% 3$ PVY $^{\mathrm{N}: O}$
$7.6 \% 12$ SYR-I

$\square \quad 9.5 \% \quad 15$ SYR-I and SYR-II

$\square \quad 5.1 \% 8 \mathrm{~N}: O$ and $\mathrm{N}-\mathrm{Wi}$

$2.5 \%$ ( $1 \mathrm{NTN}(\mathrm{A})$ and $(\mathrm{B}) \mathrm{C}$

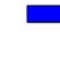

-

$\mathbf{2 . 5 \%} 4$ SYR-II or [SYR-III and N-Wi]

$22.2 \% 35 \mathrm{PVY}^{\mathrm{N}-\mathrm{Wi}}$

$5.1 \% 8 \mathrm{SYR}-$ II and SYR-III

$1.9 \% 3$ NTN(A) and (B)

$\square 1.3 \% 2[\mathrm{NTN}(\mathrm{A})$ and $(\mathrm{B})]$ and [N:O or N-Wi or NA-PVYN]

\section{$21.5 \% 34$ SYR-II}

$6.3 \% 10 \mathrm{~N}-\mathrm{Wi}$ and SYR-II

\footnotetext{
2.5\% 4 [SYR I and SYR-II] and [N:O or N-Wi]

$0.6 \% 1$ [NTN(A) and (B)] or NA-PVYN and [N:O or N-Wi] and N

$\square \quad 1.3 \% 2$ [SYR I and SYR-III] or [SYR-IIand SYR III] and [N or NTN(A) or (B) or NA-PVYN] and [N:O or N-Wi] $\square \quad 0.6 \% 1[\mathrm{O}$ and $\mathrm{N}: \mathrm{O}]$ or $\mathrm{N}-\mathrm{Wi}$
}

Fig. 2. The occurrence of Potato virus Y (PVY) strains in potato leaf samples collected in the northeast provinces Heilongjiang and Inner Mongolia, China. PVY was detected using the RT-PCR procedure described in Chikh-Ali et al. (2010b). The occurrence rate is expressed in percent. 
less than $0.5 \%$ between $\mathrm{HN} 2$ and the PCR-predicted PVYNTN-NW SYR-I isolates HLJ-9-4 and HLJ-6-1; 1.4-1.6\% between SYR-II2-8 and the PCR-predicted PVY ${ }^{\text {NTN-NW }}$-SYR-II isolates SC-1-1-2 and INM-W-369-12;0.7\% between Mb112 and the PCR-predicted $\mathrm{PVY}^{\mathrm{N}: \mathrm{O}}$ isolate HLJ-30-2; and $1.6-1.7 \%$ between SGS-AG and the PCR-predicted PVY ${ }^{\mathrm{N}-W \mathrm{i}}$ isolates HLJ-C-429 and HLJ-BDH-2.

As anticipated, one to four recombination events were detected in the isolates: one in the PVY ${ }^{\mathrm{N}: \mathrm{O}}$ isolate HLJ-30-2, two in the PVY ${ }^{\mathrm{N}-\mathrm{Wi}}$ isolates HLJ-C-429 and HLJ-BDH-2, three in the PVY ${ }^{N T N-N W}$-SYR-I isolates HLJ-9-4 and HLJ-6-1, and four in the PVYNTN-NW $-S Y R-I I$ isolates SC-1-1-2 and INM-W-369-12 (Table 2). The RJ $(\mathrm{N} \rightarrow \mathrm{O})$ in HLJ-30-2 and the PVY ${ }^{\mathrm{N}: \mathrm{O}}$ representative Mb112 occurred at the same location that corresponds to nt 2,405 of $\mathrm{PVY}^{\mathrm{N}}-\mathrm{N} 605$ (X97895), one of the presumed parent strains of all of the recombinant isolates. The PVY ${ }^{\text {NTN-NW }}-$ SYR-I isolates HLJ-9-4 and HLJ-6-1 shared identical RJs at the P2/P3 junction $(\mathrm{N} \rightarrow \mathrm{O}$, nt 2,514 in $\mathrm{X} 97895), \mathrm{VPg}$ gene $(\mathrm{O} \rightarrow \mathrm{N}$, nt 5,865 in X97895), and NIb gene $(\mathrm{N} \rightarrow \mathrm{O}$, nt 8,567 in X97895) (Table 2). Although the two differed slightly for the RJ in NIb with HN2, the first PVY ${ }^{\text {NTN-NW }}$-SYR-I isolate reported in China (Hu et al. 2009a), the shift (nt 8,567 for HLJ-9-4 and HLJ-6-1 versus nt 8,557 for HN2) was not considered significant due to the overlapping breakpoint ranges of the RJs. The PVY ${ }^{\mathrm{N}-\mathrm{Wi}}$ isolates HLJ-C-429 and HLJ-BDH shared the same recombination junctions $\left(\mathrm{O} \rightarrow \mathrm{N}\right.$, nt 494-500; and $\mathrm{N} \rightarrow \mathrm{O}$, nt 2,392) with the PVY ${ }^{\mathrm{N}: \mathrm{Wi}}$ representative isolate SGS-AG. Among the PVY ${ }^{\text {NTN-NW}}$-SYR-II isolates, the $\mathrm{RJ}$ in $\mathrm{P} 1(\mathrm{O} \rightarrow \mathrm{N})$ occurred at the same positon (nt 500 of X97875), and the RJ in $\operatorname{VPg}(\mathrm{O} \rightarrow \mathrm{N})$ took place largely at the same location (corresponding to nt 5,826-5,865 of X97875) despite some insignificant differences (nt 5,865 for SC-1-1-2 and INM-W369-12, and 5,826 for SYR-II-2-8). The same was observed for the $\mathrm{RJ}(\mathrm{N} \rightarrow \mathrm{O}$ ) in NIb, which occurred at nt 8,557-8,567 (nt 8,557 for SC-1-1-2, and 8,567 for INM-W-369-12 and SYR-II-2-8). However, the $\mathrm{RJ}(\mathrm{N} \rightarrow \mathrm{O})$ in $\mathrm{P} 2 / \mathrm{P} 3$ occurred at nt 2,514 for SC-1-1-2, which is approximately $100 \mathrm{nt}$ downstream of that in INM-W-369-12 and SYR-II-2-8, exceeding the RJ shift threshold of 80 nt suggested by Green et al. (2018). As demonstrated previously, the Eu-PVY ${ }^{N T N}$ isolate Hungarian (M95491), the very first recombinant PVY ${ }^{\text {NTN }}$ ever identified (Nie and Singh 2003a) contained three RJs at nt 2,416 $(\mathrm{N} \rightarrow \mathrm{O})$, 5,826 $(\mathrm{O} \rightarrow \mathrm{N})$, and 9,175 $(\mathrm{N} \rightarrow \mathrm{O})$. The PVY ${ }^{\mathrm{NTN}-\mathrm{NW}}$ SYR-III isolate SYR-III-L4 had four RJs that were located at positons corresponding to nt $693(\mathrm{~N} \rightarrow \mathrm{O}), 2,416(\mathrm{O} \rightarrow \mathrm{N}), 5,826(\mathrm{~N} \rightarrow \mathrm{O})$, and
$8,433(\mathrm{O} \rightarrow \mathrm{N})$ in $\mathrm{X} 97875$ (Table 2). A schematic diagram of the recombinant structure of the isolates is shown in Supplementary Figure S2.

Phylogeny of PVY in China. More than 340 complete genome sequences of PVY have been deposited to GenBank to date, and among them, 42, including the isolates reported in this study, were from China. To reveal the phylogenetic relationship among the Chinese isolates as well as with the representative isolates of welldefined strains, phylogenetic trees were constructed. All the isolates from this study clustered with a respective "representative" isolate of a particular strain, consistent with the RT-PCR categorizing and RE analysis results: HLJ-9-4 and HLJ-6-1 grouped with the PVY ${ }^{\text {NTN-NW }}$ SYR-I representative HN2; SC-1-1-2 and INM-W-369-12 clustered to the PVY ${ }^{\mathrm{NTN}-N W_{-S Y R}}$-II representative SYR-II-2-8; HLJ30-2 grouped with the PVY ${ }^{\mathrm{N}: \mathrm{O}}$ representative Mb112; and HLJ-C429 and HLJ-BDH-2 clustered with the $\mathrm{PVY}^{\mathrm{N}-\mathrm{Wi}}$ representative SGS-AG. Despite the fact that the PVY isolates from China were isolated from at least five host species including the nonsolanaceous species $K$. indica (Wang et al. 2012b), all but four clustered with different recombinant PVY isolates of potato origin (Fig. 3). Among the four "non-recombinant" isolates, two (SD-D, JQ663997, and WA-13-quan, HM590407) grouped to PVYO, whereas the other two (Guiyang, KU724101, and ME162, JQ971975) clustered with PVY ${ }^{\mathrm{N}}$ (Fig. 3). Previous analysis by Green et al. (2017) indicated that the isolate ME162 belongs to strain NE-11, a recombinant derived from NA-PVY ${ }^{\mathrm{N} / N T N}$, Eu-PVY ${ }^{\mathrm{N}}$, and an unknown strain (Green et al. 2018; Lorenzen et al. 2008). It is noteworthy that the sources of the isolates were mainly non-potato hosts: tobacco for Guiyang and WA-13-Quan (Cai et al. 2017), and K. indica for ME162 (Wang et al. 2012b). Among the recombinant clusters, unique groups may represent the "unusual" recombinants that were observed by Green et al. (2017). The tobacco isolate 1101 (KC296434), which laid be-

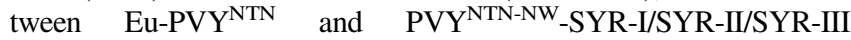
groups, is an example. Recombination analysis of the isolate using SimPlot revealed that it had an additional recombination event to that found in PVY ${ }^{\mathrm{NTN}-N{ }_{-}}$-SYR-I: an N-derived segment ( nt 8,980 to $9,070)$ in the mid-CP gene. Within the PVY ${ }^{\text {NTN-NW }}-S Y R-I I / S Y R-$ III cluster, isolateHC-2-quan (HM590406) shared similar RJs 1 to 3 with SYR-II-2-8, but differed for RJ 4 ( nt 8,567 in SYR-II-2-8 versus $\sim$ nt 9,188 in HC-2-quan). The isolates 1104 (KC296436) and FZ10 (JN083842) contained the first three RJs, but lacked the

Table 2. Recombination junction positions in Potato virus $Y(\mathrm{PVY})$ isolates

\begin{tabular}{|c|c|c|c|c|c|c|}
\hline \multirow[b]{3}{*}{ Isolate } & \multicolumn{6}{|c|}{ Recombination breakpoint positions (nt) (number in brackets are nucleotide locations in PVY isolate N605) ${ }^{a}$} \\
\hline & Gene & P1 (190-1,014) & P2 $(1,015-2,409) /$ P3 $(2,410-3,504)$ & VPg $(5,719-6,282)$ & NIb $(7,015-8,571)$ & $\mathrm{CP}(\mathbf{8 , 5 7 2 - 9 , 3 7 2 )}$ \\
\hline & $\overline{\text { Strain shifting }}$ & $\mathbf{O} \rightarrow \mathbf{N}$ & $\mathbf{N} \rightarrow \mathbf{O}$ & $\mathbf{O} \rightarrow \mathbf{N}$ & $\mathbf{N} \rightarrow \mathbf{O}$ & $\mathbf{N} \rightarrow \mathbf{O}$ \\
\hline \multicolumn{3}{|l|}{ HLJ-9-4 } & $2,513(2,514)$ & $5,864(5,865)$ & $8,566(8,567)$ & \\
\hline \multicolumn{3}{|l|}{ HLJ-6-1 } & $2,513(2,514)$ & $5,864(5,865)$ & $8,566(8,567)$ & \\
\hline \multicolumn{2}{|c|}{ HLJ-C-429 } & 489 (494) & $2,387(2,392)$ & & & \\
\hline \multicolumn{2}{|c|}{ HLJ-BDH-2 } & $495(500)$ & $2,387(2,392)$ & & & \\
\hline \multicolumn{2}{|c|}{ SC-1-1-2 } & $495(500)$ & $2,509(2,514)$ & $5,860(5,865)$ & $8,552(8,557)$ & \\
\hline \multicolumn{2}{|c|}{ INM-W-369-12 } & $495(500)$ & $2,387(2,392)$ & $5,860(5,865)$ & $8,562(8,567)$ & \\
\hline \multicolumn{2}{|c|}{ HLJ-30-2 } & & $2,405(2,405)$ & & & \\
\hline \multicolumn{2}{|c|}{ HN2 (GQ200836) (SYR-I) } & & $2,513(2,514)$ & $5,864(5,865)$ & $8,556(8,557)$ & \\
\hline \multicolumn{2}{|c|}{$\begin{array}{l}\text { SYR-II-2-8 (AB461451) } \\
\text { (SYR-II) }\end{array}$} & $477(500)$ & $2,393(2,416)$ & $5,803(5,826)$ & $8,544(8,567)$ & \\
\hline \multicolumn{2}{|c|}{$\begin{array}{l}\text { SGS-AG (JQ924288) } \\
(\mathrm{N}-\mathrm{Wi})\end{array}$} & $464(500)$ & $2,356(2,392)$ & & & \\
\hline \multicolumn{2}{|c|}{$\begin{array}{l}\text { Mb112 (AY745491) } \\
\text { (N:O) }\end{array}$} & & $2,404(2,405)$ & & & \\
\hline \multicolumn{2}{|c|}{$\begin{array}{l}\text { Hungarian (M95491) } \\
\text { (Eu-NTN) }\end{array}$} & & $2,416(2,416)$ & $5,826(5,826)$ & & $9,175(9,175)$ \\
\hline \multicolumn{2}{|c|}{$\begin{array}{l}\text { SYR-III-L4 (AB461454) } \\
\text { (SYR-III) }\end{array}$} & $670(693)$ & $2,393(2,416)$ & $5,803(5,826)$ & $8,410(8,433)$ & \\
\hline
\end{tabular}




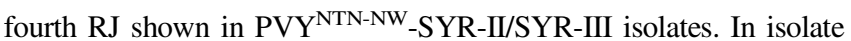
1107 (KC296439), five RJs at $\sim$ nt 500, 2,417, 5,856, 8,579, and 9,095 were detected by SimPlot, which is consistent with that reported by Green et al. (2018). Between PVY ${ }^{\mathrm{NTN}} / \mathrm{PVY}^{\mathrm{NTN}-\mathrm{NW}}$-SYR-I/SYR-
II/SYR-III and PVY ${ }^{\mathrm{N}: \mathrm{O} / \mathrm{PVY}} \mathrm{N}^{\mathrm{N}-\mathrm{Wi}}$ groups, three clades were observed: SD1/DF clade, 9703-3/1116 clade, and GF YL20 clade. All isolates in these clades appeared to contain uncommon recombination events shown by Green et al. (2018).

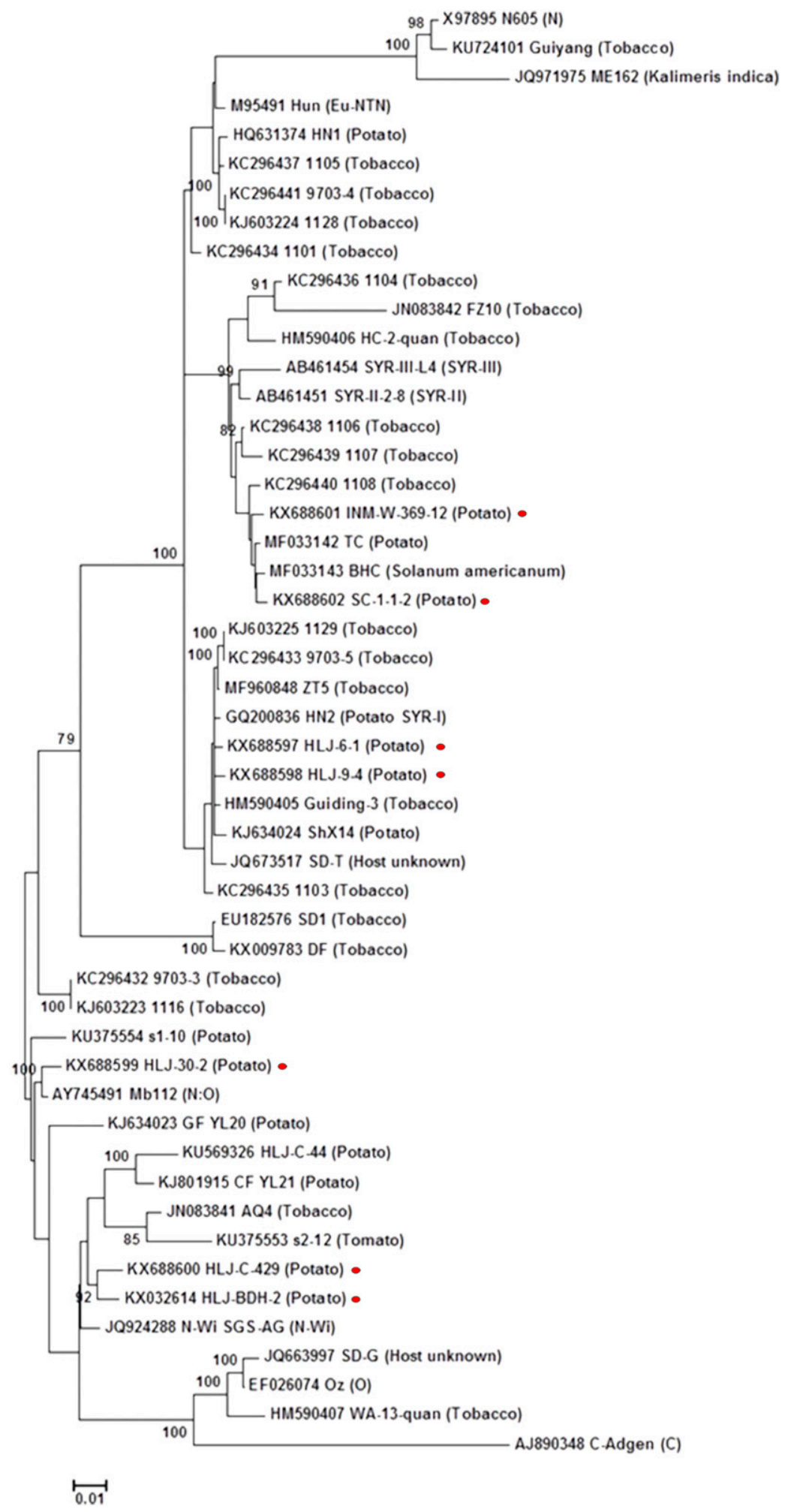

Fig. 3. Phylogeny of Potato virus $Y$ (PVY) from China. Full length sequences of PVY isolates from China, together with sequences of the representing isolates of characterized strains, were used for phylogenetic analysis employing MEGA7 with the maximum likelihood method (Kumar et al. 2016). The scale bar represents genetic distance. Numbers at the nodes indicate the percentage of replicate trees in which the associated taxa clustered together in the bootstrap test (1,000 replicates). The GenBank accession number, isolate name, and host species are shown. The characterized strains include: PVYN (N, representative isolate N605, X97895), PVYO (O, representative isolate Oz, EF026074), PVY ${ }^{N T N-N W}$. SYR-I (SYR-I, representative isolate HN2, GQ200836), PVYNTN-NW-SYR-II (SYR-II, representative isolate SYR-II-2-8, AB461451), PVYN-Wi (N-Wi, representative isolate SGS-AG, JQ924288), PVY ${ }^{\mathrm{N}: \mathrm{O}}$ (N:O, representative isolate Mb112, AY745491), Eu-PVY ${ }^{\mathrm{NTN}}$ (Eu-NTN, representative isolate Hungarian, M95491), PVY ${ }^{\mathrm{NTN}-\mathrm{NW}}-\mathrm{SYR}-\mathrm{III}$ (SYR-III, representative isolate SYR-III-L4, AB461454), and PVYC (C, representative isolate Adgen, AJ890348). 
Pathogenicity of PVY isolates. Four isolates, namely HLJ-30-2, HLJ-C-429, HLJ-9-4, and INM-W-369-12 representing PVY ${ }^{\mathrm{N}: \mathrm{O}}$, $\mathrm{PVY}^{\mathrm{N}-\mathrm{Wi}}$, PVY ${ }^{\mathrm{NTN}-\mathrm{NW}_{-}}$-SYR-I, and PVY ${ }^{\mathrm{NTN}-\mathrm{NW}_{-}}$SYR-II, were assessed for their pathogenicity on potato cultivar Kexin 13, one of the most common potato varieties in the region. The isolates led to varying degrees of symptom severity, ranging from unnoticeable to severe, upon mechanical inoculation. The PVY ${ }^{\mathrm{N}-\mathrm{Wi}}$ isolate HLJ-C429 did not incite any visible symptoms on the cultivar during the complete course of the experiment (Fig. 4; Table 3). The other isolates, however, induced recognizable symptoms on the plants. At 7 DPI, necrosis started to emerge on the leaves/leaflets inoculated with HLJ-9-4 and INM-W-369-12, and the symptoms became profound by 10 DPI (Fig. 4; Table 3 ). The inoculated leaves died and dropped off the plants inoculated with INM-W-369-12, HLJ-9-4, and HLJ$30-2$ at $12-14,12-14$, and 14-16 DPI, correspondingly. Necrotic spots/necrosis on upper uninoculated leaves and necrotic streaks on the stems were also observed on the plants (Fig. 4). On the PVY $^{\text {NTN-NW }}-S Y R-I I$ isolate INM-W-369-12 inoculated plants,

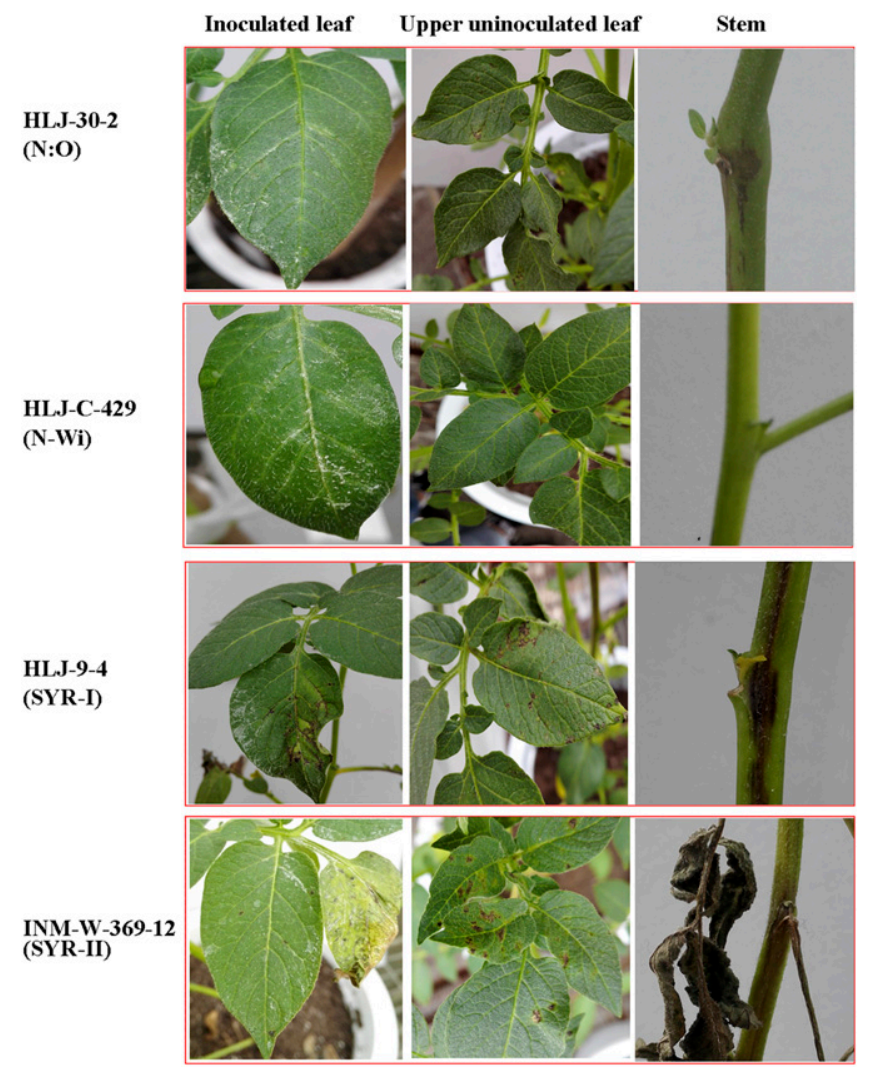

Fig. 4. Development of symptoms on Kexin 13 plants upon mechanical inoculation with different isolates of Potato virus $Y$ (PVY) belonging to different strain groups. Left column, inoculated leaves at 10 days postinoculation (DPI); middle column, upper uninoculated leaves at $16 \mathrm{DPI}$; right column, stem at $20 \mathrm{DPI}$. Virus-free plants of cultivar Kexin 13 were inoculated mechanically at the $\sim 5$-leaf stage with different isolates of PVY as described in the text, and kept in the greenhouse. N:O, PVY O; N-Wi, PVY ${ }^{N-W i}$; SYR-I, PVY ${ }^{N T N-N W}$-SYR-I; SYR-II, PVY ${ }^{N T N-N W}$-SYR-II. severe necrosis spread rapidly, leading to death of the plants within 24 DPI (Table 3). On the PVYNTN-NW $-S Y R-I$ isolate HLJ-9-4 infected plants, the necrosis also spread to upper parts of the plants, but at a relatively milder level and a slower pace (Table 3 ). The plants remained alive for up to 5 weeks post inoculation. The symptoms on the PVY ${ }^{\mathrm{N}: O}$ isolate HLJ-30-2 infected plants were the mildest in comparison with those that were infected with HLJ-9-4 or INM-W-369-12 (Supplementary Figure S3). Due to the premature death of INM-W369-12 infected plants, small tubers were obtained. Interestingly, despite the small sizes, necrotic ringspots were observed on the tubers. Similar symptoms were also observed on tubers of HLJ-9-4 infected plants but not on tubers of HLJ-30-2 and HLJ-C-429 infected plants.

\section{Discussion}

PVY has received a great deal of attention for both its economic significance and biological and molecular complexities (Karasev and Gray 2013). Prior to the emergence and discovery of the potato tuber necrosis inducing strain of PVY (i.e., PVYNTN) in the mid 1980s (Beczner et al. 1984), three strains, namely $\mathrm{PVY}^{\mathrm{O}}, \mathrm{PVY}^{\mathrm{N}}$, and $\mathrm{PVY}^{\mathrm{C}}$, were considered to be the major strain groups, with $\mathrm{PVY}^{\mathrm{O}}$ being the predominant strain in most potato production areas worldwide (Shukla et al. 1994; Sigvald 1985). However, a noticeable strain structure change has been recorded over the last three decades, first in Europe, then in the Middle East (Chikh-Ali et al. 2010a, b), Japan (Ogawa et al. 2012), and North and South America (Blanchard et al. 2008; Gray et al. 2010; Karasev and Gray 2013; MacKenzie et al. 2018; Nie et al. 2013; Singh et al. 2008). In most regions of the world, the recombinant strains (i.e., Eu-PVY ${ }^{\mathrm{NTN}}, \mathrm{PVY}^{\mathrm{N}-\mathrm{Wi}} / \mathrm{PVY}^{\mathrm{N}: \mathrm{O}}$, $\mathrm{PVY}^{\mathrm{NTN}-\mathrm{NW}}$ ) have become the predominant strain groups. Consistent with this worldwide trend, recombinant strains were found to account for $99 \%$ of all PVY populations in potato crops in northeast provinces in China in this study. In Europe, the Eu-PVYNTN is the predominant strain, followed by PVY ${ }^{\mathrm{N}-\mathrm{Wi}}$ (Kamangar et al. 2014); in the United States, PVY ${ }^{\mathrm{N}-\mathrm{Wi}}$ is the predominant strain, followed by EuPVY $^{\text {NTN }}$ (Funke et al. 2017; Karasev et al. 2011); in the Middle East such as Syria, PVY ${ }^{\text {NTN-NW}}$-SYR-I and PVY ${ }^{\text {NTN-NW }}$-SYR-II are the predominant strains, followed by $\mathrm{PVY}^{\mathrm{N}-\mathrm{Wi}}$ (Chikh-Ali et al. 2008); and in Canada, Eu-PVY ${ }^{\mathrm{NTN}}$ has recently become the predominant strain, followed by $\mathrm{PVY}^{\mathrm{N}: \mathrm{O}}$ (MacKenzie et al. 2018). Interestingly, our results show that PVY ${ }^{\mathrm{NTN}-\mathrm{NW}}-\mathrm{SYR}-\mathrm{II}$ and $\mathrm{PVY} \mathrm{Y}^{\mathrm{N}-\mathrm{Wi}}$ are the predominant strains in China, occurring with equal frequency, followed by PVY ${ }^{\mathrm{NTN}-\mathrm{NW}}-\mathrm{SYR}-\mathrm{I}, \mathrm{PVY}^{\mathrm{N}: \mathrm{O}}$, and Eu-PVY ${ }^{\mathrm{NTN}}$

China is a country that does not officially import seed potatoes that are lower than the nuclear class from other countries such as the Netherlands (Xingyao Xiong, personal communication). How and where these recombinant strains originated remains unclear. One possible route is that these strains were introduced through germplasm exchange. There are many tens of research and development institutes, universities, and private enterprises conducting research and/or development on potato in China, and large amounts of potato material from various sources outside of China were brought in to the country as a part of research and development activities. The coexistence of tobacco and potato productions in many regions might have contributed to the diversification of PVY as well. Indeed, approximately $50 \%$ of the complete PVY genome sequences from China deposited in GenBank were from isolates collected in tobacco plants.

Table 3. Symptoms in potato cultivar Kexin 13 induced by Potato virus $Y$ (PVY) isolates belonging to N:O, N-Wi, SYR-I, and SYR-II strain groups ${ }^{\mathrm{a}}$

\begin{tabular}{|c|c|c|c|c|c|c|c|}
\hline \multirow[b]{3}{*}{ Isolate } & \multirow[b]{3}{*}{ Phylogroup } & \multicolumn{6}{|c|}{ Potato cultivar Kexin 13} \\
\hline & & \multicolumn{2}{|c|}{ Local symptoms } & \multicolumn{3}{|c|}{ Systemic symptoms } & \multirow{2}{*}{$\frac{\text { Tubers }}{\text { PTNRD }}$} \\
\hline & & $\mathbf{L L}$ & VN & SNS & PD & LF & \\
\hline HLJ-30-2 & $\mathrm{N}: \mathrm{O}$ & - & + & + & - & + & - \\
\hline HLJ-C-429 & $\mathrm{N}-\mathrm{Wi}$ & - & - & - & - & - & - \\
\hline HLJ-9-4 & SYR-I & + & + & + & - & + & + \\
\hline HLJ-369-12 & SYR-II & + & + & + & + & + & + \\
\hline
\end{tabular}

a VN, vein necrosis; LL, local lesion (necrotic spots); SNS, systemic necrotic stem streaking; PD, premature plant death; LF, leaf fall; PTNRD, potato tuber necrotic ringspot disease; N:O, PVY ${ }^{\mathrm{N}: \mathrm{O}} ; \mathrm{N}-\mathrm{Wi}$, PVY ${ }^{\mathrm{N}-\mathrm{Wi}}$; SYR-I, PVYNTN-NW$-S Y R-I ;$ SYR-II, PVYNTN-NW $-S Y R-I I$. 
These sequences spread in all clades, ranging from nonrecombinant $\mathrm{PVY}^{\mathrm{O}}$ and $\mathrm{PVY} \mathrm{N}^{\mathrm{N}}$ to various recombinant clades/subclades (Fig. 3).

The first complete genome sequence for a PVY isolate that was thought to be $\mathrm{PVY}^{\mathrm{N}}$ was reported in 1989 (Robaglia et al. 1989), followed by Eu-PVY ${ }^{\mathrm{NTN}}$ (Thole et al. 1993), PVYO (Singh and Singh 1996), Eu-PVY ${ }^{\mathrm{N}}$ (Jakab et al. 1997), NA-PVY ${ }^{\mathrm{NTN}}$, and NA-PVYN (Nie and Singh 2003a) and PVY ${ }^{\mathrm{N}: \mathrm{O}}$ (Nie et al. 2004). The analysis of these sequences led to the development of multiplex RT-PCR for the differentiation of $\mathrm{PVY}^{\mathrm{O}}$ from $\mathrm{PVY}^{\mathrm{N}} / \mathrm{PVY}^{\mathrm{N}: \mathrm{O}} / \mathrm{PVY}^{\mathrm{NTN}}$ (Nie and Singh 2002) and the detection of $\mathrm{PVY}^{\mathrm{N}: \mathrm{O}} / \mathrm{PVY}^{\mathrm{N}-\mathrm{Wi}}$ and $\mathrm{Eu}-$ $\mathrm{PVY}^{\mathrm{NTN}}$ by targeting the recombination events in the recombinant strains (Nie and Singh 2003b). As more isolates have been characterized biologically and sequenced fully, improved multiplex PCR assays have been developed to simultaneously detect up to 11 strains of PVY based on their characteristic sequence features (Chikh-Ali et al. 2010a, b; Hu et al. 2009a; Lorenzen et al. 2006). Indeed, using the multiplex PCR reported by Chikh-Ali et al. (2010b), the strain structure of PVY in potato crops in the northeast region of China was revealed for the first time. Nevertheless, despite the effectiveness of the PCR assay for the detection of strain types, detailed sequence analysis is still necessary; it will not only be able to confirm the PCR results but will also be capable of revealing any subtle or major sequence variations. This is particularly true for the revelation of the precise recombination switching points and the interstrain variations. For example, the RT-PCR assay indicated that the isolates SC-1-1-2 and INM-W-369-12 were PVY ${ }^{\text {NTN-NW }}$-SYR-II type, a strain with four RJs at P1 gene, the P2/P3 junction, VPg gene, and NIb gene (ChikhAli et al. 2008), but it cannot determine whether the isolates share identical RJ switching points with each other and with other known PVY $^{\text {NTN-NW }}$-SYR-II isolates such as SYR-II-2-8. Only after analysis of RJs in the isolates were the precise RJ switching points revealed: SC-1-1-2 and INM-W-369-12 shared identical RJs at P1 $(\mathrm{O} \rightarrow \mathrm{N}$, nt $500)$ and $\mathrm{VPg}(\mathrm{O} \rightarrow \mathrm{N}$, nt 5,865), and differed slightly for the RJ at $\mathrm{NIb}$ gene $(\mathrm{N} \rightarrow \mathrm{O}$, nt 8,557 for SC-1-1-2 versus 8,567 for INM-W369-12), but the two differed significantly for the $\mathrm{RJ}(\mathrm{N} \rightarrow \mathrm{O})$ in the $\mathrm{P} 2 / \mathrm{P} 3$ junction. The RJ in SC-1-1-2 is approximately $100 \mathrm{nt}$ downstream of that in INM-W-369-12 and the PVY ${ }^{\text {NTN-NW }}$-SYR-II representative isolate SYR-II-2-8, which exceed the RJ shift threshold of 80 nt suggested by Green et al. (2018). The variations among the PVYNTN-NW - SYR-II isolates suggest that they might have evolved differently and have entered potato crops through different sources. Another interesting aspect regarding the RJs is the spectrum of each recombination hotspots. It appears that recombination events typically occurred in five regions: (1) the $5^{\prime}$ end of the $\mathrm{P} 1$ gene $(\mathrm{O} \rightarrow \mathrm{N}$, occurring in $\mathrm{PVY}^{\mathrm{N}-\mathrm{Wi}}$ and PVY $\left.{ }^{\mathrm{NTN}-\mathrm{NW}}-\mathrm{SYR}-\mathrm{II}\right)$; (2) the P2/P3 junction area $(\mathrm{N} \rightarrow \mathrm{O}$, occurring in most recombinant isolates); (3) the VPg gene $\left(\mathrm{O} \rightarrow \mathrm{N}\right.$, occurring in Eu-PVY ${ }^{\mathrm{NTN}}, \mathrm{PVY}^{\mathrm{NTN}-\mathrm{NW}_{-}}$-SYR-I, PVY NTN-NW SYR-II, and PVYNTN-NW $-S Y R-I I I) ;(4)$ the NIb gene $(\mathrm{N} \rightarrow \mathrm{O}$, occurring in PVY ${ }^{\text {NTN-NW }}$-SYR-I, PVY ${ }^{\text {NTN-NW }}$-SYR-II and PVY ${ }^{\text {NTN-NW }}$-SYRIII); and (5) the 3 '-end of the $\mathrm{CP}$ gene $(\mathrm{N} \rightarrow \mathrm{O}$, occurring in Eu$\left.\mathrm{PVY}^{\mathrm{NTN}}\right)$. Hotspot one spans $\sim$ nt 494 to 693 corresponding to X97895; hotspot two spans $\sim$ nt 2,350 to 2,550; hotspot three spans $\sim$ nt 5,600 to 5,800; hotspot four ranges from $\sim$ nt 8,400 to 8,800; and hotspot five covers $\sim$ nt 9,100 to 9,200.

Cultivar Kexin 13 was determined to be susceptible to PVY infection when it was released (Sun et al. 2001). Different levels of symptoms were incited by the isolates belonging to different strains: no noticeable foliar or tuber symptoms by the $\mathrm{PVY}^{\mathrm{N}-\mathrm{Wi}}$ isolate HLJ-C-429; intermediate systemic necrosis on the foliage and symptom-free on the tubers by the PVY ${ }^{\mathrm{N}: \mathrm{O}}$ isolate HLJ-30-2; severe foliar systemic necrosis and PTNRD by the PVY ${ }^{\mathrm{NTN}-N W}-\mathrm{SYR}-\mathrm{I}$ isolate HLJ-9-4; and extremely severe systemic foliar necrosis, early plant death, and PTNRD by the PVY ${ }^{\text {NTN-NW }}$-SYR-II isolate INMW-369-12. Necrosis in foliage, including both local and systemic necrosis, has been considered an indicator of hypersensitive reaction (HR), a response controlled by an $N$ gene (Jones and Vincent 2018). Most $N$ genes are strain specific. For instance, the $N y$ gene, which is present in many potato cultivars and breeding clones (MacKenzie et al. 2018; Nie et al. 2015), is specific to $\mathrm{PVY}^{\mathrm{O}}$, whereas the $N c$ gene is specific to $\mathrm{PVY}^{\mathrm{C}}$, and the $N z$ gene is specific to PVYZ (Karasev and Gray 2013; Singh et al. 2008). Recently, a putative $N d$ has been reported in potato (Jones and Vincent 2018). It is particularly noteworthy that in the $\mathrm{Nz}$-possessing potato lines, HR was triggered by L26 (Chikh-Ali et al. 2014), a PVYZ ${ }_{-N T N}$ isolate that shares the characteristic $\mathrm{RJ}$ features $(\mathrm{N} \rightarrow \mathrm{O}$ at the $\mathrm{P} 2 / \mathrm{P} 3$ junction, $\mathrm{O} \rightarrow \mathrm{N}$ at the $\mathrm{VPg}$ gene, and $\mathrm{N} \rightarrow \mathrm{O}$ at the $3^{\prime}$-end of the $\mathrm{CP}$ gene) with Eu-PVYNTN isolates (Hu et al. 2009b; Kerlan et al. 2011) such as PVY ${ }^{\text {NTN }}$-Hungarian (Nie et al. 2004) and PVY ${ }^{\mathrm{NTN}}$-HN1 (Hu et al. 2011). Considering all the elements required for HR, it is logical to speculate that Kexin 13 possesses an $\mathrm{Nz}$ (or $\mathrm{Nz}$-like) gene and the isolates HLJ-30-2, HLJ-9-4, and INM-W-369-12 were PVYZ (precisely, PVYZ-N:O, PVY ${ }^{Z}-S Y R-I$, and PVY ${ }^{Z}-S Y R-I I$, respectively). When Kexin 13 was inoculated with these $P V Y^{Z}$ isolates, HR (foliar necrosis) was triggered. The possibility of the presence of an unknown PVY ${ }^{\mathrm{N}: \mathrm{O}}$ specific $N$ gene in Kexin 13 cannot be excluded. It is interesting to note that only SYR-I and SYR-II induced PTNRD in Kexin 13, suggesting that foliar HR and PTNRD were controlled separately by different genes in the host. Clearly, more systematic studies on various potato germplasms including those with known $N$ genes using a more broad spectrum of PVY strains (e.g., $\mathrm{PVY}$, PVY $Y^{\mathrm{N}}$, Eu-PVY ${ }^{\mathrm{NTN}}, \mathrm{PVY}^{\mathrm{Z}}-\mathrm{NTN}, \mathrm{PVY}^{\mathrm{N}: \mathrm{O}}, \mathrm{PVY}^{\mathrm{N}-\mathrm{Wi}}, \mathrm{PVY}^{\mathrm{NTN}}$ $\left.{ }^{N W}-S Y R-I, P V Y^{N T N-N W}-S Y R-I I\right)$ is needed in order to achieve concrete conclusions.

\section{Literature Cited}

Bai, Y., Han, S., Gao, Y., Zhang, W., Fan, G., Qiu, C., Shen, Y., Zhang, S., Shang, H., Nie, X., and Wen, J. 2017. Pathogenicity of Potato virus $Y$ strains in different potato varieties. Acta Agric. Boreali-occidentalis Sin. 27:1713-1720.

Beczner, L., Horvath, H., Romhanyi, L., and Forster, H. 1984. Studies on the etiology of tuber ringspot disease in potato. Potato Res. 27:339-352.

Blanchard, A., Rolland, M., Lacroix, C., Kerlan, C., and Jacquot, E. 2008. Potato virus $Y$ : a century of evolution. Curr. Top. Virol. 7:21-32.

Cai, W., Yang, H., Shen, J., Zou, W., and Gao, F. 2017. Determination of Potato virus $Y$ strain in China based on phylogenetic and recombination analyses of the complete genomic sequences. Acta Laser Biol. Sin. 26:350-359.

Chikh-Ali, M., Alruwaili, H., Vander Pol, D., and Karasev, A. V. 2016. Molecular characterization of recombinant strains of Potato virus $Y$ from Saudi Arabia. Plant Dis. 100:292-297.

Chikh-Ali, M., Maoka, T., and Natsuaki, K. T. 2008. Whole genome sequence and characterization of a novel isolate of PVY inducing tuber necrotic ringspot in potato and leaf mosaic in tobacco. J. Phytopathol. 156:413-418.

Chikh-Ali, M., Maoka, T., Natsuaki, T., and Natsuaki, K. T. 2010a. PVY ${ }^{\text {NTN-NW }}$ a novel recombinant strain of potato virus y predominating in potato fields in Syria. Plant Pathol. 59:31-41.

Chikh-Ali, M., Maoka, T., Natsuaki, K. T., and Natsuaki, T. 2010b. The simultaneous differentiation of Potato virus $Y$ strains including the newly described strain PVY ${ }^{\text {NTN-NW }}$ by multiplex PCR assay. J. Virol. Methods 165:15-20.

Chikh-Ali, M., Rowley, J. S., Kuhl, J., Gray, S. M., and Karasev, A. V. 2014 Evidence of a monogenic nature of the $\mathrm{Nz}$ gene conferring resistance against Potato virus $Y$ strain $Z$ (PVYZ) in Potato. Am. J. Potato Res. 91:649-654.

Chinese Ministry of Agriculture. 2017. China agriculture statistical report. China Agriculture Press, Beijing.

Funke, C. N., Nikolaeva, O. V., Green, K. J., Tran, L. T., Chikh-Ali, M., QuinteroFerrer, A., Cating, R. A., Frost, K. E., Hamm, P. B., Olsen, N., Pavek, M. J., Gray, S. M., Crosslin, J. M., and Karasev, A. V. 2017. Strain-specific resistance to Potato virus $Y$ (PVY) in potato and its effect on the relative abundance of PVY strains in commercial potato fields. Plant Dis. 101:20-28.

Gao, M., Luo, Q., Liu, Y., Zhu, C., Yi, X., and Zhang, Q. 2013. Development trend analysis on China's potato industry. Chin. Potato J. 27:243-247.

Gray, S., Boer, S. D., Lorenzen, J., Karasev, A., Whitworth, J., Nolte, P., Singh, R., Boucher, A., and Xu, H. 2010. Potato virus Y: an evolving concern for potato crops in the United States and Canada. Plant Dis. 94:1384-1397.

Green, K. J., Brown, C. J., Gray, S. M., and Karasev, A. V. 2017. Phylogenetic study of recombinant strains of Potato virus $Y$. Virology 507:40-52.

Green, K. J., Brown, C. J., and Karasev, A. V. 2018. Genetic diversity of potato virus Y (PVY): sequence analyses reveal ten novel PVY recombinant structures. Arch. Virol. 163:23-32

Han, S., Gao, Y., Fan, G., Zhang, W., Qiu, C., Zhang, S., Bai, Y., Zhang, J., and Spetz, C. 2017. A novel recombined Potato virus $Y$ isolate in China. Plant Pathol. J. 33:382-392.

Hu, X., He, C., Xiao, Y., Xiong, X., and Nie, X. 2009a. Molecular characterization and detection of recombinant isolates of Potato virus $Y$ from China. Arch. Virol. 154:1303-1312.

Hu, X., Nie, X., He, C., and Xiong, X. 2011. Differential pathogenicity of two different recombinant $\mathrm{PVY}^{\mathrm{NTN}}$ isolates in Physalis floridana is likely determined by the coat protein gene. Virol. J. 8:207.

Hu, X. J., Meacham, T., Ewing, L., Gray, S. M., and Karasev, A. V. 2009b. A novel recombinant strain of Potato virus $Y$ suggests a new viral genetic determinant of vein necrosis in tobacco. Virus Res. 143:68-76. 
Jakab, G., Droz, E., Brigneti, G., Baulcombe, D., and Malnoë, P. 1997. Infectious in vivo and in vitro transcripts from a full-length cDNA clone of PVY-N605, a Swiss necrotic isolate of potato virus Y. J. Gen. Virol. 78:3141-3145.

Jones, R. A. C. 1990. Strain group specific and virus specific hypersensitive reactions to infection with potyviruses in potato cultivars. Ann. Appl. Biol. 117:93-105.

Jones, R. A. C., and Vincent, S. 2018. Strain-specific hypersensitive and extreme resistance phenotypes elicited by Potato virus $Y$ among 39 potato cultivars released in three world regions over a 117 year period. Plant Dis. 102:185-196.

Kamangar, S. B., Smagghe, G., Maes, M., and Jonghe, K. D. 2014. Potato virus $Y$ (PVY) strains in Belgian seed potatoes and first molecular detection of the N-Wi strain. J. Plant Dis. Prot. 121:10-19.

Karasev, A. V., and Gray, S. M. 2013. Continuous and emerging challenges of Potato virus Y in potato. Annu. Rev. Phytopathol. 51:571-586.

Karasev, A. V., Hu, X., Brown, C. J., Kerlan, C., Nikolaeva, O. V., Crosslin, J. M., and Gray, S. M. 2011. Genetic diversity of the ordinary strain of Potato virus $Y$ (PVY) and origin of recombinant pvy strains. Phytopathology 101:778-785.

Kerlan, C., Nikolaeva, O. V., Hu, X., Meacham, T., Gray, S. M., and Karasev, A. V. 2011. Identification of the molecular make-up of the Potato virus $Y$ strain $\mathrm{PVY}^{\mathrm{Z}}$ : genetic typing of PVY ${ }^{\mathrm{Z}}$-NTN. Phytopathology 101:1052-1060.

Kumar, S., Stecher, G., and Tamura, K. 2016. MEGA7: Molecular evolutionary genetics analysis version 7.0 for bigger datasets. Mol. Biol. Evol. 33: 1870-1874.

Lole, K. S., Bollinger, R. C., Paranjape, R. S., Gadkari, D., Kulkarni, S. S., Novak, N. G., Ingersoll, R., Sheppard, H. W., and Ray, S. C. 1999. Full-length human immunodeficiency virus type 1 genomes from subtype C-infected seroconverters in India, with evidence of intersubtype recombination. J. Virol. 73:152-160.

Lorenzen, J. H., Meacham, T., Berger, P. H., Shiel, P. J., Crosslin, J. M., Hamm, P. B., and Kopp, H. 2006. Whole genome characterization of Potato virus $Y$, isolates collected in the western USA and their comparison to isolates from Europe and Canada. Arch. Virol. 151:1055-1074.

Lorenzen, J. H., Nolte, P., Martin, D., Pasche, J. S., and Gudmestad, N. C. 2008. NE11 represents a new strain variant class of Potato virus Y. Arch. Virol. 153:517-525.

Lu, D. Q., Qiu, C. L., Wang, S. P., Li, Y., and Gao, Y. F. 2009. Development of cDNA dimeric probes and its application in diagnosis of Potato spindle tuber viroid. Acta Hortic. Sin. 36:1538-1544.

MacKenzie, T. D. B., Lavoie, J., Nie, X., and Singh, M. 2018. Differential spread of Potato virus $Y$ (PVY) strains $\mathrm{O}, \mathrm{N}: \mathrm{O}$ and $\mathrm{NTN}$ in the field: implications for the rise of recombinant PVY strains in New Brunswick, Canada. Am. J. Potato Res. 95:301-310.

Martin, D. P., Murrell, B., Golden, M., Khoosal, A., and Muhire, B. 2015. RDP4: Detection and analysis of recombination patterns in virus genomes. Virus Evol. 1:vev003.

Nie, B., Singh, M., Sullivan, A., Murphy, A., Xie, C., and Nie, X. 2012. Response of potato cultivars to five isolates belonging to four strains of Potato virus $Y$. Plant Dis. 96:1422-1429.

Nie, X., Liang, Z., Nie, B., Murphy, A., and Singh, M. 2015. Studies on varietal response to different strains of Potato virus $Y$ (PVY) reveal hypersensitive resistance in Exploits to PVY ${ }^{\mathrm{O}}$ and extreme resistance in F87084 to all tested strains. Am. J. Potato Res. 92:23-31.

Nie, X., Singh, M., Pelletier, Y., and Mclaren, D. 2013. Recent advances on Potato virus $Y$ research in Canada. Am. J. Potato Res. 90:14-20.

Nie, X., and Singh, R. P. 2002. A new approach for the simultaneous differentiation of biological and geographical strains of Potato virus $Y$ by uniplex and multiplex RT-PCR. J. Virol. Methods 104:41-54.
Nie, X., and Singh, R. P. 2003a. Evolution of North American PVY ${ }^{\mathrm{NTN}}$ strain Tu 660 from local $\mathrm{PVY}^{\mathrm{N}}$ by mutation rather than recombination. Virus Genes 26:39-47.

Nie, X., and Singh, R. P. 2003b. Specific differentiation of recombinant PVY N:O and PVY ${ }^{\text {NTN }}$ isolates by multiplex RT-PCR. J. Virol. Methods 113:69-77.

Nie, X., Singh, R. P., and Singh, M. 2004. Molecular and pathological characterization of N:O isolates of the Potato virus $Y$ from Manitoba, Canada. Can. J. Plant Pathol. 26:573-583.

Ogawa, T., Nakagawa, A., Hataya, T., and Ohshima, K. 2012. The genetic structure of populations of Potato virus $Y$ in Japan; based on the analysis of 20 full genomic sequences. J. Phytopathol. 160:661-673.

Qu, D., and Xie, K. 2009. Vigorous promotion and implementation of the 3-year generation seed system to improve China's seed potato quality and potato production level. Pages 7-12 in: Potato Production and Food Safety. Chen, Y., and Qu, D., eds. Harbin University of Technology Press, Harbin, China.

Robaglia, C., Durand-Tardif, M., Tronchet, M., Boudazin, G., Astier-Manifacier, S., and Casse-Delbart, F. 1989. Nucleotide sequence of Potato virus Y (N strain) genomic RNA. J. Gen. Virol. 70:935-947.

Shukla, D. D., Ward, C. W., and Brunt, A. A. 1994. The Potyviridae. CAB International, Wallingford, UK

Sigvald, R. 1985. Mature-plant resistance of potato plants against Potato virus $\mathrm{Y}^{\mathrm{O}}$ $\left(\mathrm{PVY}{ }^{\mathrm{O}}\right.$ ). Potato Res. 28:135-143.

Simms, P. E., and Ellis, T. M. 1996. Utility of flow cytometric detection of CD69 expression as a rapid method for determining poly- and oligoclonal lymphocyte activation. Clin. Diagn. Lab. Immunol. 3:301-304.

Singh, M., and Singh, R. P. 1996. Nucleotide sequence and genome organization of a Canadian isolate of the common strain of Potato virus Y (PVY). Can. J. Plant Pathol. 18:209-224.

Singh, R. P., Valkonen, J. P., Gray, S. M., Boonham, N., Jones, R. A., Kerlan, C., and Schubert, J. 2008. Discussion paper: the naming of Potato virus $Y$ strains infecting potato. Arch. Virol. 153:1-13.

Sun, Y., Xia, P., Sheng, W., Teng, W., and Zhang, H. 2001. Breeding and cultivation techniques of a new vegetable potato variety, Kexin 13, with good quality and high yield. Heilongjiang Agr. Sci. 6:44-45.

Thole, V., Dalmay, T., Burgyan, J., and Balazs, E. 1993. Cloning and sequencing of Potato virus $Y$ (Hungarian isolate) genomic RNA. Gene 123:149-156.

Tian, Y. P., Liu, J. L., Zhang, C. L., Liu, Y. Y., Wang, B., Li, X. D., Guo, Z. K., and Valkonen, J. P. T. 2011. Genetic diversity of Potato virus $Y$ infecting tobacco crops in China. Phytopathology 101:377-387.

Wan, X., Qia, C., Zhao, S., Li, R., Li, L., and Guo, Z. 2015. Molecular identification of tobacco Potato virus $Y$ strains in Heilongjiang tobacco planting areas. Tob. Sci. Technol. China 48:13-18.

Wang, B., Jia, J. L., Wang, X. Q., Wang, Z. Y., Yang, B. H., Li, X. D., and Zhu, X. P. 2012a. Molecular characterization of two recombinant potato virus $Y$ isolates from China. Arch. Virol. 157:401-403.

Wang, B., Ma, Y., Zhang, Z., Wu, Z., Wu, Y., Wang, Q., and Li, M. 2014. Potato viruses in China. Crop Prot. 30:1117-1123.

Wang, F., Wu, Y. H., Gao, Z. L., Zhou, B. G., and Guo, L. 2012b. First report of Potato virus $Y$ in Kalimeris indica in China. Plant Dis. 96:1827.

Wang, L., Li, X. B., Suo, H. C., An, K., Luo, H. M., and Liu, X. J. 2017. Soft rot of potatoes caused by Bacillus amyloliquefaciens in Guangdong province, China Can. J. Plant Pathol. 39:533-539.

Zhang, H., Xu, F., Wu, Y., Hu, H. H., and Dai, X. F. 2017. Progress of potato staple food research and industry development in China. J. Integr. Agric. 16: 2924-2932. 